\title{
REVISING ENVIRONMENTAL LAW THROUGH THE PARADIGM OF GOVERNANCE
}

\author{
Grace Ladeira Garbaccio \\ Pos-doutoranda pela Universidade de Limoges/França. Doutora em Direito pela Universidade de Limoges \\ e título reconhecido pela Universidade Federal de Santa Catarina (UFSC). Mestre em Direito pela \\ Universidade de Limoges/França. Parecerista da Revista da Advocacia-Geral \\ da União (AGU) e do CONPEDI. \\ Email:glgarbaccio@hotmail.com \\ Michel Prieur \\ Professor Emérito da Universidade de Limoges, França. Diretor científico do Centro de Pesquisas \\ Interdisciplinares em Direito Ambiental, de Ordenamento Territorial e Urbanístico da Universidade \\ de Limoges, França. Presidente do Centro Internacional de Direito Ambiental Comparado, ONG \\ internacional com status consultivo e acreditação permanente diante \\ do Conselho Econômico e Social da ONU. \\ Danielle Mendes Thame Denny

Doutoranda pela Universidade Católica de Santos (UNISANTOS), com bolsa da Coordenação
de Aperfeiçoamento de Pessoal de Nível Superior (CAPES). Mestre em Comunicação na
Contemporaneidade, pela Faculdade Cásper Líbero (FCL). Com especializações em: Diplomacia
Econômica, pela Universidade Estadual de Campinas; Direito Tributário, pela Pontifícia Universidade
Católica de São Paulo (PUC-SP); e Política pela Escola de Governo da Universidade de São Paulo.

\begin{abstract}
This article analyzes the Brazilian environmental normative production and its lack of effectiveness and efficiency under the dominion of symbolic power. Besides being the environment a common good the ones who have the competence to rule about it are very few public offices. The result is a constrained rule of law unable to encompass the complexity of the environmental challenges, and a lack of indicators to assess the effectiveness of environmental law: its existence and implementation in quantitative and qualitative values.The argument of this paper is that environmental law should be measured, produced and applied in the light of the governance paradigm empowering multistakeholders throughmultiple channels of influence causing synergistic, overlapping, or even contradictory actions, but efficiently influencing actions to deal with the causes of the environmental problems. The present analysis was based on bibliographical references using the hypothetical deductive method.
\end{abstract}

Keywords: legallegitimacy crisis; environmental legal production; legal measurements. 


\section{REVISITAÇÃO DO DIREITO AMBIENTAL POR MEIO DO PARADIGMA DA GOVERNANÇA}

\section{RESUMO}

Este artigo analisa a produção normativa ambiental brasileira e sua falta de eficácia e eficiência sob o domínio do poder simbólico. Apesar de ser o meio ambiente um bem comum, aqueles que têm competência para regulá-lo são apenas entes políticos. O resultado é um Estado de Direito constrangido incapaz de abranger a complexidade dos desafios ambientais e a falta de indicadores para avaliar a eficácia do Direito Ambiental: sua existência e implementação em valores quantitativos e qualitativos. Este estudo aborda o direito ambiental deve ser medido, produzido e aplicado à luz do paradigma da governança, capacitando os múltiplos atores através de múltiplos canais de influência que geram ações sinérgicas, sobrepostas ou mesmo contraditórias, mas influenciando eficientemente as ações para lidar com as causas dos problemas ambientais. A presente análise foi baseada em referências bibliográficas utilizando o método dedutivo hipotético.

Palavras-chave: legitimidade jurídica; produção legal ambiental;medidas legais. 


\section{INTRODUCTION}

Environmental law has the duty to protect and restore the integrity of eco-system, which support human live on the planet. Innovative legal instruments and mechanisms are needed to accomplish this mission. Conventional forms of strict rule of law command and control mechanisms are inefficient, time demanding and costly. The widespread and diffuse lack of environmental effectiveness with respect to many environmental laws must be addressed and overcome. In order to improve its effectiveness a new grounding paradigm for environmental law is needed to guide the elaboration, interpretation and enforcement of legislation.

According to St. Thomas Aquinas, in his work Treatise of the Law, the norms produced by man must: dictate practical reason, ordered toward the common good; be made by one who has care for the community; and also go to the process of being promulgated. Then the usingof reason by those who are in charge of the "community care" must make every law aimed at the common good. Therefore established power does not have the right to surpass the power of who has care for the community and all laws have the same status and have egalitarian motivation, not obeying a specific mean. (Aquino, 1991).

From a perspective of social and legal analysis, particular legal statutes are instituted in accord with human reason for the good of civil society, these reasons prove to be variables and subject to conformation in the different social contexts, an observation that was already perceived by the author at that time. In fact, the point made in reference to the work of St. Thomas Aquinas is that, despite the theological characteristic of his work, in the middle ages, the will was the personal motivation of the production of laws, and therefore reflects the importance of the primacy of reason. Thus, thinking about normative production as the fruit of the social environment is to admit its many vulnerabilities and justifications arising from the very multiplicity that composes it.

From the environmental point of view, as well as a legal inference from the juridical field ${ }^{1}$, according to Bourdieu (2007), the imposition of

1 The "juridical field" is a Bourdieu's conception; a "field" is an area of structured, socially patterned activity or "practice," in this case disciplinarily and professionally defined. Like a magnet the "field" and its "practices" have special senses according to Bourdieu (2007). Bourdieu's analyses explain this invisible but forceful influence of the field upon patterns of behavior in our case, behavior in the environmental legal world. The legal field can be defined by its practices and its legal speeches, "determined by a side, for the specific relations of force that gives its structure and orient the struggles of competition or, more precisely, the conflicts of competence, and, on the other side, the internal logic of the legal works limits in each moment the space of possibility, and in this way, the universe of the 
the law on the various segments that make societies revealthemselves to be conflicting and to reflectdisputed interests, visions and conceptions. Prerogatives, which would serve as instruments guaranteeing the so-called "common and diffuse rights," "social interest," and "healthy environment," are subjected to various and flexible interpretations according to the interests of the disputed fields. This illustrateshow the elaboration and execution of the environmental norms are permeated and susceptible to different techniques that dispute the social environment.

And in these disputes, the use of different types of techniques (capital, economic, political, among others) is a relevant factor, as a mechanism of imposition, subjecting other practices to social invisibility and compromising the effectiveness of the environment as a common good, established in the Brazilian Bill of Rights -CRFB of $1988^{2}$ as to be used equitably by everybody.

\section{BRAZILIAN REGULATORY PRODUCTION AND THE ENVIRONMENTAL LEGITIMATION CRISIS}

In order to understand these articulations in the environmental legal production, it is necessary, in principle, to locate historically the elements that integrate the discussion. We can situate the current stage of social demands in relation to the environment, whose disputes over time have been shown to be the preservation of natural resources, as a conflict field that is called diffuse orright of the commons. This is implemented in a way of legitimizing discourses, such as employed in the economic market perspective.

Thus, starting from this premise of how social relations, legal prescriptions and normative declarations are produced, also in the environmental area, these elements allow unveiling the confrontation of the different social agents in the environmental and legal field by determining which material and symbolic values will be presented as legitimate object of environmental preservation policies.

In a relational inference to the concept of field presented by Bourdieu (2007), environmental normative production has an intrinsic characteristic the expression and space of forces, due to the asymmetry,

proper legal solutions". (BOURDIEU, 2007, p.211).

2 Art.225, caput: "todos têm direito ao meio ambiente ecologicamente equilibrado, bem de uso comum do povo e essencial à sadia qualidade de vida, impondo-se ao Poder Público e à coletividade o dever de defendê-lo e preservá- lo para as presentes e futuras gerações". 
of the diversities, proper to social structures. According to Bourdieu (2007), this field is represented by structures of objective relations, under clashes of forces, and struggles that aim to transform the interaction that gives legitimacy to a certain structure and which has in its organization the consequence of the agents' attitudes, and how they relate to their representatives.

According to the author, this field produces a particular social game. In order to participate, one must be involved in the game, emphasizing the necessary influence and shocks that mark the existence of disputes and the use of different capitals. In the author's view, capital would not only be an economic value attributed to a good, but a 'charisma', a symbolic value that allows its holder to enjoy a power over others in his field. "It's a credit based on the belief and recognition that the agents give them." (BOURDIEU, 2007. p.187 / 188)

In this way, norms are made considering the social interactions, their different practices, and conflicting character that surrounds them, as well as the field and the historical context, to identify the involved actors and their conceptions about the nature. In this sense, when there are norms produced with the specific purpose of permitting or prohibiting certain environmental conduct, one can perceive the externalization of values, and practices that one wishes to see prevailing. And thus, one has the dispute for the classification of the environmental goods and its normalization centered in the axis between protection and exploration. In other words, it is the game of interests externalized with the use of different values and that when considering the environmental theme from a homogeneous view, it excludes and causes invisibility to other forms of interaction with nature, even independent of norms about existence of the controversial "nature conservation". (ZHOURI et al., 2005).

With regard to the historical theoretical analysis of the institution of norms and their social structures, we can observe it in the context of changes in which "the nature of man has proved to be very fragile as an absolute foundation of rights" (BOBBIO, 1992, p. 16), marking the end of the natural-age $\mathrm{e}^{3}$ era and guiding new bases of rights and social relations. According to the Tridimensional Theory of Law of Miguel Reale (2008) there is a dynamic unity between the factual reality-axiological-normative, ie, "an element of fact, ordered values in a policy development process."

3 According to the natural-law theory, law is a natural condition inherent to the human being, a set of norms or first moral principles, which are immutable, consecrated or not in the legislation of society, since it results in the nature of things and of man. 
Therefore we currently live under a statute in which actual realityaxiological-normative can not remain the simple antithesis of eachother domain, making it necessary the simultaneous coexistence of these elements (Reale, 2008, p.520).

According to the author, "the rights are inscribed in a reality referring to values", that are a cultural fact, as effect and cause. These are factual, axiological, and normative elements that juxtapose, based on events connected in a Representative Democratic Republic, such as the Brazilian, with the preferences of opinion reflected in the autonomy of political party activities, given the legitimacy - in theory - of all established representations.

Nevertheless, these representations are determined by the material (economic) differences between the groups that dispute the power and establish paradigms of rights and duties that vary according to the social changes. In this way, it can be observed that even the most fundamental rights are produced within social relations and their experiences in time. In this sense Bobbio (1992, p.16) states, "many rights, even the most diverse among them, even the more or less fundamental, were subordinated to the generous and complacent human nature."

(...)The list of rights has changed and continues to change with changes in historical conditions, that is, the lack of interests of the ruling classes, the means available for their realization, social transformations, etc. (BOBBIO, 1992, p.16)

It is a historical processthat results from social struggles and manifestations. Therefore rights not yet claimed at eighteenth-century declarations and not even mentioned as fundamental / social and collective rights, are now proclaimed with great ostentation in recent declarations, such as the preservation of the animal lives and forests preservation. According to Bobbio (1992, p.19), it is proved "that there are no fundamental rights by nature. What seems fundamental in a historical age and in a particular civilization is not fundamental in other times and cultures. "Still in this sense, the author affirms that the rights structured in norms are product not of the nature, but of the human civilization; as historical rights, they are susceptible to transformations.

In other words, rights are fruits of social transformations, and daily struggles that mirror achievements and also dominations. In this light,they are the expression of a correlation of forces in a given society. It 
is not the rules that create rights, but the rights that establish what should or should not be converted in rules. "The legal struggle is not restricted to the simple search for changes of laws, as if they modified the world. It is social struggles that establish new foundations and create new social practices. " (AGUIAR, 2002, p.29)

And in this social context conflicts emerge. The current environmental question is posed as a challenge of the social structure, however, different spheres of life in society are still guided by the logic of capitalist accumulation that launches its networks on different fields and guarantees the sovereign representation of their demands, often based on the model created by the State that in no way is related to the right to the environment as an ecologically balanced right and therefore not in the best position to rule common goods. The interactions and conjectures established from the production until the publication ${ }^{4}$ of the legal norms are associated to different political, socioeconomic, environmental and other entanglements.

Bobbio (1992: 40 and 132) asserts that law is "a complex of principles and norms designed to guarantee life in society and the existence of society itself." For the author, "the rights and duties thus regulated are not absolute or immutable, and are manifested at certain moments of history with greater or lesser constraining force on social reality." Norms are therefore submitted to the forces of human relations and are reflections of conjectures established by social groups, whether equanimity or representative of specific agents.

Similarly, Hobsbawm (2000) affirms that it is the society that determines the creation of rights and duties and that these are the signposts of social interrelations. In this perspective, there can be a defense in favor of punctual social segments or, the silence of other competitive visions and perspectives in the scenario of conflict ${ }^{5}$. About social interactions as a source of rights, Bobbio states:

4 The publication of the legal norm is formally the final act before becoming law. It is the act by which the decree, sanction and promulgation of the law are brought to the knowledge of the components of the State-society and state organs, finally, to the knowledge of all, so that they owe obedience to it. (MELLO, 1979, p.264).

5 The notion of social conflict refers to the classics of sociology (Marx, Durkheim, Weber). In this dissertation, the term conflict will also be applied as the dispute between distinct groups with asymmetric forms of appropriation of the material and symbolic world, integrating different orders of justification, according to Acselrad (2004). 
The list of human rights has changed and continues to change, with the change of historical conditions, that are the lack of interests or the interests of the classes in power, the means available for their realization, technical transformations, etc. Rights that were declared absolute at the end of the eighteenth century, with the priority sacré et inviolable, were subjected to radical limitations in contemporary declarations. (1992, p.32).

It is important to remember that, however fundamental the rights are, they are always associated with a determined social context, therefore, changeable, produced in time and by social agents. For example, environmental rights that are fundamental - a premise for life itself - are also influenced by social struggles and disputes. In this sense, Bobbio (1992) states:

The rights of humankind are undoubtedly a social phenomenon and from the various points of view from which they can be examined human rights, however fundamental they may be, are historical rights, that is, they are rights born in certain circumstances, brought about by struggles in defense of new freedoms against old powers, and born gradually, not all at once and not once and for all. (1992, pp. 43 and 68)

Rights, expressed through norms and as a social product, besides the regulatory character, are endowed with meanings that society imprints on them, also called "symbolic function". This function, however, loses space when the current power ${ }^{6}$ socially validates the dominant criteria. It is necessary to consider that the very act of regulating, the presumption of fairness and justice inserted in these acts already expresses the fragility and risk to which these acts are succumbed. And in this sense, allowing the accommodation of different material and symbolic values in a way to avoid centralizing practices. In this sense, Santos (1996):

In addition to the concrete effects of guarantee and the recognition and implementation of certain rights, it is fundamental to understand the importance of its symbolic effect in social relations, insofar as such effect is an inducing / guiding element of social practices. (1996, p.38).

6 According to Bourdieu (2007), symbolic power is a power that the subject gives to the one who exercises it, a credit with which he credits him, a fides, an author, which he entrusts to him and owes his strength to the fact that Relations of power expressed in it only manifest in an unrecognizable form of relations and senses. 
It is from this perspective that the exercise of giving meaning to space, also in its symbolic sphere, is essential to understand the domain of society over the production of norms and their later validity / effectiveness ${ }^{7}$. This is because law does not only satisfy the functional requirements of a complex society, with its customs, practices that interfere in the material and immaterial field, and must also take into account the conditions of its integration, of acceptability, and theclaims about its validity.

However, throughout history, there is a political struggle for the definition of rights, their validity and the ways of implementation, because, these rights are not free from the diversity of interests that surround them. By breaking with naturalism and absolutism, rights become the fruit of a society in movement, expressed through its practices and symbolic values, which represented gains but also risks by delegating to man the power to "define the right ${ }^{8 "}$. According to Habermas, "law in modern societies faces the discussion between facticity and validity, consensus and arbitration" (HABERMAS, 2003, p.143). Corroborating this theoretical reasoning, Leffort (1987):

Rights are not dissociated from the awareness of rights ... but it is no less true that this awareness of rights is so much better shared when they are declared, when the power affirms them, when the marks of liberties become visible through laws. (1987, p.57)

In this comparison, there is a field where the interrelations are strained in search of legitimation of their actions, in search of how and what should be converted in law fromtheeffectivestruggle for power. And these social relations have their own dynamics and laws that are driven by internal disputes, movements that characterize society and its space.

It is observed, therefore, that in this context of classificatory, environmental and normative disputes, actions are effectively able to modify the structure of these fields as in a constant struggle for power

\footnotetext{
7 In brief synthesis, the difference between validity, effectiveness and effectiveness of legal norms: The validity refers to the existence of a rule made by a competent authority to do so. If the national congress, for example, creates a law, if the president edits a provisional measure, even though these rules are unconstitutional, it has a valid legal existence because it was made by a competent authority, and even presumed to be constitutional. The existence of the norm in the legal plane is known as validity which is not confused with effectiveness. That is because, legal effectiveness is the aptitude of the standard to be applied to concrete cases. The rule that is effective is one that is capable of producing its own effects. As for effectiveness, a norm has it when it fulfills the function for which it was created, also called the social function of the norm.
}

8 Expression used by Bourdieu (2007) in "The Symbolic Power", chapter VIII.

Veredas do Direito, Belo Horizonte, · v.15 · n.31 - p.11-36 · Janeiro/Abril de 2018 
(BOURDIEU, 2007). These modifications, the established relations, and the products of these arrangements tell us about power and its conjectures. Elements that are also revealed when we observe the scenario of classification disputes, the normalization of common use of all, and the introduction of a hegemonic meaning of environmental sustainability that representsnot only the varied conceptions experienced by the social agents that inhabit different spaces, but also their interactions with nature and the symbolic values that guide their practices. It is also in this light that differences exist between, for example, those who exploit natural resources as means of production and capital increase, and those who depend on the forest to supply their material demands without necessarily representing monetary value, but for who nature as a way of life, cultural manifestations, etc.

Amidst these different perceptions lies the constant dispute for the power to establish and make conceptions, practices and norms prevail, as in an exercise of "reality-building power that tends to establish a gnostic based order: the immediate meaning of the world," according to Bourdieu (2007, p.9). From the perspective of symbolic power the author describes:

The different classes and fractions of classes are involved in a properly symbolic struggle to impose the definition of the social world more in accordance with their interests and to impose the field of the taking of ideological positions reproducing in a transfigured form the field of social positions (BOURDIEU 2007, p.11).

This 'symbolic power' can be exercised in various ways and is associated with people's own way of interacting, as well as being present everywhere, from economic relations, religious manifestations, scientific knowledge, etc. Also composing this power are ideologies, which, for the author, owe their structure and functions more specific to the social conditions of their production and circulation, "that is to say, the functions which they fulfill in the first place for the specialists in competition for the monopoly of the competence (religious, artistic, etc)and, secondarily, for non-specialists “(BOURDIEU, 2007).

It is common for power to present itself in a forceful and effective manner, and why not to say, fearful, since it has been effected in a subtle way, almost without imposing itself, through the practices, of the habitus ${ }^{9}$

9 The concept of habitus, according to Bourdieu, is the power exerted in a forceful and effective way, and why not to say, fearful, since it is subtly effected, through the practices, of the habitus of people who incorporate these behaviors into the social environment with symptoms Of automatism and absence of resistance. It is a kind of sense of the game that does not need to reason in order to be oriented and situated in a rational way in space, a systematic functioning of the structured body. (Bourdieu, 2007) 
of people who incorporate these behaviors into the social environment with symptoms of automatism and absence of resistance. In this sense, Bourdieu (2007) writes:

Symbols are instruments par excellence of social integration: as instruments of knowledge and communication, they make possible the consensus about the meaning of the social world that contributes fundamentally to the reproduction of the social order: illogical integration is the condition of moral integration (BOURDIEU, 2007, p.10).

According to the author, the symbols would be produced to serve the ruling class.

The field of symbolic production is a microcosm of the symbolic struggle between classes: it is because their interests serve in the internal struggle of the field of production (and only in this measure) that producers serve the interests of the outer groups of the field of production (BOURDIEU, 2007, p.12).

Thus, the struggle for the dominion of symbolic power is fought in the different daily conflicts, in the search for the power to impose arbitrary instruments (though ignored as such) of knowledge and expression (taxonomies) that alter social reality.

Relationships are envisaged by the power struggle and this, gives its holder, the prerogative of "telling the right" (BOURDIEU, 2007), to make his speech prevail in whatever field. Thus, it can be observed that disputes can be legal, economic and symbolic, and the scope of their effects may not be limited to a particular territory, as well as the phase in which the conflict is manifested. In this sense, he argues (ZHOURI, 2010, p.18) "it is necessary to consider the different views on the use of space, which configure the cognitive basis for the discourses and actions of the groups involved in environmental conflicts."

In fact, social actors are included in the possession of certain capitals and in certain social groups such as the political, economic, artistic, cultural, etc. And according to this belonging, each social actor is establishing its habitus, conditioned to it's positioning and the social struggle for space and voice.

Thus, when one has actors from different "fields" articulating in search of the resolution of an impasse or concretizing meanings for 
an environmental good, one has the characterization of a society, a time and its rights and values in detriment of all others. They are symbols that are intended as instruments, par excellence, of social integration, making possible the reproduction of the established order.

According to Zhouri (2010), these relations of power between social subjects combine certain meanings of environment, space and territory, consolidate certain meanings, notions and categories that come to be as the most legitimate and capable of sustaining social and political actions. "The conceptual perspective that guides this reflection refers to a certain tradition present in the sociology of conflicts, in which social subjects dispute the legitimacy of certain conceptions and actions from a specific capital" (BOURDIEU 2007: 83).

As well as rights and duties, social order and worldview are constructed over time, through the various interactions between social agents in which the confrontations are recurrent. It is evident that this construction of rights represents disputes at a given moment and space since it is born as an expression of a field of forces. (REALE, 2008. p.532)

Also in this field, social agents are structured through disputes of those who establish such rights, classify them and on whom they will impose themselves and for whom it will be guaranteed. The asymmetry, intrinsic characteristic of society, is one more dimension of socio juridical conflict, and to understand it through actions one need to identify its field, its demands and the values in question.

In this sense Habermas (2003) states that:

The reconstructive analysis of the judge or citizen from the perspective of the participant is directed to the significant contents incorporated in the normative substrate and to the ideas of values from which it is possible to clarify the claim to the legitimacy or ideal validity of a legal system. In this sense, what is important is the representations of man on the meaning and value of certain propositions of law. (HABERMAS, 2003. p.98)

Indeed, the empirical analysis, formed by faith in legitimacy, by the situation of interests, by the sanctions and circumstances, therefore, the logic of the situations of action is that they make it possible to explain the empirical validity and the factual imposition of the expectations of behavior institutionalized according to the right. (HABERMAS, 2003, p.98).

Thus, in observing that society is the source and destination of legal 
norms at the same time, it requires more than the ideological consideration of the conservation of natural resources and their exploitation. Ensuring the actual effectiveness / validity of the signed rights without allowing it to become a commitment to serve timely interests is a challenge. In this sense, it is necessary, although not sufficiently, to pursue the intrinsic requirements that a norm must obey in order to be considered valid and juxtaposed to the social fact and to consider the different social fields, as well as the socio-environmental demands, without privileging a group. As for society's observance of norms, Reale (2008 p. 531) asserts that these should not be within the limits of unfailing observance, nor should they fall to the lower level of absolute noncompliance. Thus, the context of different confluences to influence and result from social relations, whose demands change in time and as a result of the field of each group.

\section{THEORETICALANALYSIS OF THE ENVIRONMENTAL LEGAL FIELD}

It is necessary to reconstruct the objective space of social arrangements and relations between the positions that the different agents occupy and maintains in function of the distribution structure of the diverse species of capital or of power by which they compete in the social fields. Secondly, it is a matter of incorporating the representations that influence and determine the reciprocal objective conditions, through the analysis of the social agents in question and the conflicts arising from disputes involving environmental goods.

In this sense, the legal field is constituted historically and functions according to its internal logic of relations, including with powers to legitimize, authorize and consecrate certain "operators of law", according to the notion of legal field presented by Bourdieu (2007: 219222). For this author, the legal field concerns a specific, autonomous social space in which the "operators" compete with each other for the "monopoly of the right to speak the law". The recognized capacity to interpret and apply normative instruments, which impose a legitimate view of the social world, allows one to give reasons for the relative autonomy of this field (BOURDIEU, 2007, p.220)

When we look at environmental disputes, we have the construction of these "structures", either through concepts that are disseminated and 
consecrated ideas or through norms to enforce practices that are intended to be transformed into a true social habitus. In this perspective, environmental legal norms function as a mechanism to obtain this legitimacy as it enables specific social agents to conform environmental laws according to their practices and visions.

Bringing the discussion to the field of environmental disputes, these visions and practices are subject to divergences and each one defends its conception on the nature and way of preservation of the natural resources. And that, by adopting "hegemonic" and indeterminate concepts such as "right" and "everyone's duty" to the balanced ecosystem and preservation, as can be inferred from article 225 of the CRFB / $88^{10}$, it fails to contemplate these differences, Thus subjecting itself to the varied and sometimes excluding interpretations of other modes of perception and environmental interaction outside the habitus that we intend to equalize.

So, the different perceptions and social practices also reproduce modes of appropriation in different spheres in society. And in this sense, we can observe that the norm when used as technical capital, does not consider the differences and the context under which it affects, suffering then of lack of effectiveness. In this sense, the formation of social structures are organized and establish by their representations, their symbolic values making the social life dependent on a very particular theory of these representations and the behaviors that develops anchored in the belief about the value of their practices. (BOURDIEU, 2007).

The symbolic struggle for the preservation or transformation of the social world through the preservation or transformation of the worldview and the principles of vision of this world: or, more precisely, for the preservation or transformation of the divisions established between the classes through the systems and the form that the institutions establish to perpetuate the classification in force. (BOURDIEU, p.174, 2007)

Also in this perspective, Acselrad (2004, p.19) argues that "it is in the symbolic sphere that the dispute of legitimacy of the discourses

10 Art.225: "Todos tem direito ao meio ambiente ecologicamente equilibrado, bem de uso comum do povo e essencial à sadia qualidade de vida, impondo-se ao Poder Público e à coletividade o dever de defendê-lo, preservá-lo para as presentes e futuras gerações”. Constituição da República Federativa do Brasil de 1988. (BRASIL.2012.p.94). Art.225: "Everyone has the right to an ecologically balanced environment, a common use of the people and essential to a healthy quality of life, imposing on the Government and the community the duty to defend it, preserve it for the present And future generations. " Constitution of the Federative Republic of Brazil of 1988. (BRAZIL.2012.p.94) 
that seek to affirm their respective potential capacities to operate the universalization" is developed. And he adds:

If we consider the environment as a materially and symbolically contested terrain, its appointment - that is, the designation of what is environmentally benign or not - redistributes power over territorialized resources, by legitimizing / delegitimizing practices of appropriation of the material basis of societies and / or their locations. (...) the environment is an argumentative resource to which social actors resort discursively through strategies of conceptual location in the specific conditions of the struggle for 'environmental change'. (ACSELRAD, 2004, p.19)

By aiming at the space under analysis, there are established positions and relations between different agents that occupy them and maintain them in function of the structure of "capital" or power, disputed in the social field. The conceptions of these actors now approximate or differentiate themselves in the development of the legal issues much as a result of the dispute at stake. In this context, being the legal field ordered by these social conjectures, in this case, also represents the core of the conflict.

In this comparison, the theoretical concept guided by the notion of legal field (BOURDIEU, 2007) allows to unveil the true senses and logic behind the structures and social relations produced and exercised in a given social field as well as proves to be an important instrument for understandingthe social universe presented in the juridical world, which organizes and delimits spaces, where agents compete with each other for the monopoly of saying the law.

The different demands arising from the attempt to guarantee the environment as a right of the commons are social manifestations of the establishment of a socio-environmental conflict in which the legal norm is also a disputed capital in the clash that sees the hegemony of a positioning, and an established conjecture.

In effect, the structures of the fields are instituted by their agents and by the belief in the capital they possess or pursue. This means that there are no symmetrical disputes between the different fields. It is seen that the social agents and relations of force established within the institution (society) and capital are those who will say the right, legitimize this or that practice, represent and act on behalf of other social agents. In this way, 
belief in norms as an instrument of "justice" ${ }^{11}$ " and equity is also a concept under construction, liable to be driven by interests and influences of social groups that act between those who hold the power and the prerogatives of the State, where neutrality of legal norms reveals "gaps" that allow the manipulation of their effects and consequently, the adequacy according to the social agents and their needs.

In this perspective, "the establishment of a judicial space implies the imposition of a border between those who are prepared to enter the game and those who, when they are released, remain in fact excluded from it." (BOURDIEU, 2007, p.225). And here, there is a clash between the different capitals defended by each actor. In other words, there is no consensus on how to deal with environmental issues, as the official international agendas do, when they regulate the subject and the common sense seduced by the ideology of "sustainable development." According to Bourdieu (2007), the field as a structure of objective relations, as a clash of forces, struggles to transform the relationship that gives legitimacy to a given structure, has in its organization the consequence of agents' attitudes, How they relate to their representatives, "leaders".

In this sense, the conception of a dispute established within the legal field, in itself, removes the idea of the "neutrality" and "universality" of the different instruments of analysis of a legal science, that legitimates schemes of interpretation and application of law. It is also worth noting the author's observation that "the distribution of opinions in a given population depends on the state of the instruments of perception and expression available and the access that different groups have to these instruments" (BOURDIEU, 2007, p.220). This implies self-regulation of relations established within the field, which censures or liberates according to their interests.

For Bourdieu (2007, p.232) it is necessary to understand "the political discourses that are offered, whose set defines what can or can not be said at any given time." In a relational inference to the ecologically balanced environment, we have agents claiming the mastery of what is

11 There is no watertight concept of justice. In the definition of Rui Barbosa (2004) justice would be related to the equality between the people that consists of treating unequally the unequal, in the exact measure in which they are unequal, admitting to treat each one in the proportion of their equalities or inequalities. According to Sen (2011) conceptualizing justice is very difficult, however, "there is nothing that is perceived and felt as precisely as injustice" (SEM, 2011, p.9). In the definition given by the dictionary one has: moral principle in the name of which the law must be respected, assert the right of each one, quality of what is in conformity with what is right, with what is fair. (DICTIONARY HOUAISS, 2012). 
said, written, legislated and made effective in social practice, without, however, effectively representing the different social actors involved in the general context.

Juridical competence is a specific power that allows access to the legal field to be controlled, determining only the conflicts that deserve to enter into it and the specific form that must be taken to constitute proper legal debates. (BOURDIEU, 2007, p.223)

In another perspective, Acselrad (2004, p.17) notes that:

\begin{abstract}
Environmental conflicts would oppose different forms of adaptation of social actors in the natural world, together with their respective ideologies and ways of life. The reduction of the forms of appropriation of the material world to adaptive responses to the constraints of the environment does not allow, however, to capture in its entirety the political content, bearer of projects, present in the conflicts that stress the hegemonic ways by which the different social forms of space.
\end{abstract}

In effect, the production of the legal norm reveals a context of asymmetries and disputes and which reveal "the social genesis of a field, of what makes the specific need of the belief that sustains it, the role of language played in it, of material things and symbolic in dispute that are generated in it, "explains Bourdieu (2007, p.69) .The perspective that is presented as an integral part in the search for identification of social agents and the conflicts experienced by them in the environmental field, as well as the denomination in this sense, we can also observe the paradigms by which the social relation, its rights and the consequent normalizations are perceived.The fair treatment imposed by the norm distorts reality with the illusion established in the belief that "all are Equal before the Law "and that the environment is perceived by all in the same way.

According to Neto (2007, p. 125), "legal practices and discourses should be taken as a product determined by relations of social forces that structure it and by a logic that delimits spaces and" say the law "where the legal process is a social procedure in essence. "In fact, there is no simplicity in this process of "universalizing" environmental demands or even regulating the environment. The process of social differentiation of individuals and forms of appropriation of the material world configure the unequal structures and meanings they assign. 
The specific capital of the field is characterized by the formation and influence of agents, in the "representativeness" of a certain segment of society and also in personal relations. There is in this dynamic a movement of actors' positions, perpetuating a dominant view about natural resources, that is, the appropriation of nature. (ZHOURI, 2008).

In fact, there is a contradiction between reality and meanings, between "being" and "mustbe", in the light of a cultural historical conception, which depends on empirical data and the objective will. (ACSELRAD, 2004). The form of organization and performance of the social agents, as well as the objective conditions in which they lead their affirmations, guarantees the identification of the field to which they belong.

We can observe that it is not only in the discursive or symbolic field that the different meanings are present, but mainly in social practices whose complexity is as heterogeneous as in the social fields. And, the way in which concepts are articulated and discursive matrices are also developed, environmental issues are part of the "power game" around the appropriation of natural resources, whose objective is to legitimize or delegitimize social discourses and practices.

In this sense, it is observed in the legal field that the flexibilization of the environmental norms contributes to the emergence of conflicts as it transfers to the environmental field the disputes of different forces, sometimes "favoring the discourse of economic growth "and constraining those who hold dissonant practices of those pursued by the policy of attracting financial investments, whose intent" is not limited to the satisfaction of needs and overcoming material restrictions, but also consists in projecting different meanings in the world, "he says. (ASCELRAD, 2004, p.28 and $15)$.

\section{MEASUREMENTS IN THE ENVIRONMENTAL LEGAL FIELD}

The creation and testing of legal indicators are important to access the effectivity of the rules, and also to provide policymakers an additional tool for evaluating the relevance of public policies. They also contribute to a better provision of information to the general public and the economic actors conditioning a prompt and appropriate actions and contributing to better solve environmental problems. Besides these qualities measurements in the legal field are still scarce exceptions. Those in place report scientific and economic data, but none encompass qualitative and quantitative 
environmental legal indicators.

Calculating the scientific and economic is already a challenge once the national, regional, and local raw datasets have to be standardized, to permit comparative performance analyses. Doing so the Environmental Performance Index for example calibrates the values according to population, gross domestic product, and apply statistical transformations, such as inversions or logarithmic transformations (Hsu, 2016, p. 27).

The Environmental Performance Index uses legal standards especially those defined in international treaties and national policies to informthe "proximity-to-target" methodology, which assesses how close a particular country is to an identified policy target. "For example, the benchmarks for protected areas are determined through international policy targets established by the Convention on Biological Diversity"(Hsu, 2016, p. 28). This index quantifies countries to a scale of 0 to 100,0 being the farthest from the target. And the criteria are health impacts, air quality, water and sanitation, wastewater, agriculture, forests, fisheries, biodiversity and habitat, climate and energy.

To encompass environmental legal indicators, it would be an even greater challenge because legal regime on environment have been based on a variety of international treaties and national laws, and these continue to increase in number.Therefore, to access the effectiveness of this many rules, about its existence and implementation, an innovative methodology is needed.This testing of legal indicators should have quantitative and qualitative values, to examine texts, legal hierarchies and ethical and policy requirements. These indicators would facilitate comparisons through an overall environmental scorecard.

The International Center for Compared Environmental Law is conducting a research focused on International and Comparative Environmental Law in 18 countries on 5 continents. Inputs come from different legal systems: public international law, regional international law (EU, NAFTA, MERCOSUR), Common Law, Continental Law. And the purpose is to establish common indicators of the universality of environmental law which are able to overcome the fragmentation of law. These indicators will also help to assess progress or regression of environmental law as a leader of sustainable development and improvement of the environment.

States and international organizations have to been called into action to improve the existing environmental indicators such as the ones 
to measure the United Nations Sustainable Development Goals (SDGs), adopted in September 2015, constituted by 17 goals and 169 targets to guide the global development agenda (Agenda 2030). The scientific, economic and social criteria should be accompanied by the legal verification. In the actual state of metrics, the environmental law remains a mass of unexplored data, and the existing legal sociology researches restrain their scope to identify obstacles encountered in implementation of a specific legal prescription or occasionally comparing court decisions.

No quantified assessment from the perspective of environmental progress through sustainable development exists yet. Therefore, the indicators in place do not capture all the political and social reality what results in policies based on subjective opinions rather than quantified and qualified empirical data.

\section{CONCLUSION}

Given the scenario of social and environmental disputes presented, where the specific legal norms are framed by varied interests, perceptions, conceptions and agents by the different modes of appropriation / adequacy material or symbolic plan, reveals the heterogeneous social structure under construction. In this sense, a reality exposed through indicators is observed, from which it is deduced the need to analyze under which perspective the environmental protection norms are produced or also refuted.

For this, it is necessary to consider the form of interpretation of the norms and of the appropriation of the environment by its agents. To think of the environment and endowenments with meanings in which diverse social groups coexist aiming the same object with different meanings given by themit sees the emergence of a greater environmental rationality, with various political and normative connotations and not dissociated from scientific practice, nor even from the fragility of knowledge, which transformed the model of exploitation justified on a consensus about sustainable development.

The current environmental conjecture demonstrates the fragility of the mitigating actions disseminated with the idea of a "sustainable development", as well as it is not necessary to mention the separation between nature and society, but in its universalization, bringing them together in a single system based on the idea that there are relations between social and material context, worldviews and visions of nature.In fact, one 
must consider the existence of various perceptions about nature so as not to allow the paradigm of environmental conservation to prevail over the sustainable, economic, social and environmental development.

Thus, we can observe that in identifying the different perceptions about the nature and the ways in which the different social actors characterize them, they also reveal the operative actions of the conformation methodology or of disputes over values and the treatment with environmental conservation. They are elements of the socio-environmental disputes that perpetuate themselves in the social environment and, sometimes, it prevents a wider vision of nature, a look that allows reviewing the practices and their consequences, that allows to transform and to adapt the actions, as it is thesocial environment. In the theoretical perspective of the paradigm of environmental adequacy, the relations of power established between social subjects that combine certain meanings of environment.

Space and territory consolidate certain meanings, notions and categories that come to exist as the most legitimate and capable of social and political actions. Thinking about normative production in the defense of environmental goods requires the need to move away from consensus conception without, however, excluding or subordinating other competitive views and perspectives to form a sustainable dialogic development, permeable to the inputs of many and diversified interest holders.

\section{REFERENCES}

ALIER, Juan Martinez. O Ecologismo dos Pobres: Conflitos Ambientais e Linguagem de Valoração. São Paulo. Contexto, 2007.

ALIER, Juan Martinez. Correntes do ecologismo. São Paulo. Contexto, 2007.

ALIER, Juan Martinez. Economia ecológica:levando em consideração a natureza. São Paulo. Contexto, 2007.

ACSELRAD, Henri. Conflitos Ambientais no Brasil - A Atualidade do Objeto-. Ed.: Relume-Dumará, 2004.

ACSELRAD, Henri. As Praticas Espaciais e o Campo dos Conflitos Ambientais. Ed.: Relume-Dumará, 2004.

ACSELRAD, Henri. MELLO, Cacília Campello do A. BEZERRA, Gustavo 
das Neves. O que é Justiça Ambiental?. - Rio de Janeiro: Garamond, 2009.

AGUIAR, Roberto Armando Ramos. Direito do meio ambiente e participação popular. $3^{\mathrm{a}}$ edição. IBAMA. 2002

AQUINO, Tomás (Santo). Tratado da Lei. Trad. Fernando Couto. Coleção Resjurídica. 4ª edição. Porto Alegre. 1991

BARROSO, Luiz Roberto. Temas de Direito Constitucional: Tomo III . Rio de Janeiro: Ed. Renovar, 2005.

BARROSO, Luiz Roberto. Interpretação Constitucional: reflexões sobre a (nova) hermenêutica. In: novos paradigmas e categorias da interpretação constitucional. P.161, 216. Org. Bernardo Gonçalves Fernandes. Editora Jus Podvm. 2010

BECHARA, Erika. A proteção da fauna sob a ótica constitucional. São Paulo: Juarez de Oliveira, 2003.

BENJAMIN, Antonio Herman Vasconselos. Os princípios do estudo do impacto ambiental como limites da discricionaridade administrativa. Rio de Janeiro. Revista Forense, 1992, nº. 317, p. 30.

BENJAMIN, Antonio Herman Vasconselos. Estudo do impacto ambiental e Ministério Público. $7^{\circ}$ Congresso Nacional do Ministério Público, Belo Horizonte, 1987, AAMP/CONAMP.

BRASIL. Constituição (1988). Constituição da República Federativa do Brasil - texto constitucional de 5 de outubro de 1988 - atual., até Emenda Constitucional no 67 - 36 ${ }^{\mathrm{a}}$ ed. - Brasília: Câmara dos Deputados, Coordenação de Publicações, 2012.

. Lei $n^{\circ}$. 6938, de 31 de agosto de 1981. Dispõe sobre a política Nacional do Meio Ambiente, seus fins e mecanismos de formulação e aplicação, e dá outras providencias. Brasília: Diário Oficial da União (DOU) de 29/09/1981.

. Lei 4.717, de 29 de junho de 1965. Regulamenta a Ação Popular. Brasília: Diário Oficial da União (DOU) de 5.7.1965 e republicado no DOU de 8.4.1974. 
. Lei 11.284 de 2 de março de 206. dispõe sobre a gestão de florestas públicas para produção sustentável, institui o Serviço Florestal Brasileiro - (SFB) e dá outras providências. Brasília: Diário Oficial da União (DOU) de 02/03/2006.

BOBBIO, Norberto. A Era dos Direitos. - Trad. Coutinho, Carlos N. - Rio de Janeiro: Campus, 1992.

BOURDIEU, Pierre. O Poder Simbólico.- 10a ed.; tradução: Fernando Tomaz - Rio de Janeiro: Bertrand Brasil, 2007.

CARVALHO, Izabel Cristina de Moura. A invenção ecológica: narrativas e trajetórias da educação ambiental no Brasil. $3^{a}$ edição.Porto Alegre: editora da UFRGS, 2008.

CASTELLS, Manuel. A Questão Urbana. Rio de Janeiro: Paz e Terra, 2006.

CIDADE, Lucia Cony Faria. Visões de mundo, visões da natureza e a formação de paradigmas geográficos. Terra livre. São Paulo. $n^{\circ}$.:17. 2001

DAGNINO, Evelina. Cultura, cidadania e Democracia: a transformação dos discursos e práticas na esquerda Latino-Americana. In ALVAREZ, Sônia; DAGNINO, Evelina, ESCOBAR, Arturo (orgs.) Cultura e política nos movimentos sociais latino americanos. Belo Horizonte: UFMG, 2000.

DI PIETRO, Maria Silva Zanella. Direito Administrativo. $16^{\text {a }}$ Ed. São Paulo. Atlas. 2003

FILHO, Wilson Madeira et all. Direito e Justiça Ambiental. - Wilson Madeira Filho (organizador) - PPGSD/UFF - Programa de Pós Graduação em Sociologia e Direito da Universidade Federal Fluminense. - Niterói: Daugraf, 2002.

FREITAS, Vladimir Passos de. A Constituição Federal e a Efetividade das Normas Ambientais, São Paulo, Revista dos Tribunais, 2005.

FURTADO, Celso. O Mito do Desenvolvimento Econômico. Rio de Janeiro: Paz e Terra, 1974.

GONÇALVES, Carlos Walter Porto. CERRADO E DESENVOLVIMENTO Tradição e Atualidade. In: As Minas e os Gerais - Breve ensaio sobre 
desenvolvimento e sustentabilidade a partir da Geografia do Norte de Minas. Organizadores: Claudia Luz e Carlos Dayrell. Edição comemorativa dos 15 anos do Centro de Agricultura Alternativa do Norte de Minas. 2000 .

GRECO, Leonardo. Competências Constitucionais em Matéria Ambiental. Revista dos Tribunais, vol. 687, p.78, São paulo: RT, 1993.

HABERMAS, Jürgen. Direito e Democracia: entre facticidade e validade. - vol. I; $2^{\mathrm{a}}$ ed.; tradução: Flávio Beno Siebeneichler - Rio de Janeiro: Tempo Brasileiro, 2003.

HESSE, Konrad. A Forca Normativa da Constituição. Tradução de Gilmar Ferreira Mendes. Porto Alegre: Sergio Antonio Fabris Editor, 1991.

HOBSBAUM, Eric J. Mundos do Trabalho: novos estudos sobre a história operária. Trad. Barcellos W. e Bredan S. Rio de Janeiro. Paz e Terra, 2000.

HOLANDA, Sérgio Buarque de. Raízes de Brasil. 36 reimpressão. São Paulo. Companhia das Letras. 2011

HONNETH, Axel. LUTA POR RECONHECIMENTO A Gramática Moral dos Conflitos Sociais. - Tradução Luiz Repa. - Editora 34. Edição 2003.

HSU, Angel, Daniel C. Esty, Lisa Dale, Nikola Alexandre, Sam Cohen, Pamela Jao, Elena

KRELL, J. ANDREAS. A Posição dos Municípios Brasileiros no Sistema Nacional de Meio Ambiente (SISNAMA). Revista dos Tribunais, vol. 709, p. 8/19, São Paulo: RT 1994.

KHUSAINOVA, et al. "2016 Environmental Performance Index.” New Haven, CT, USA: Yale University., 2016.

LEFF, Enrique. Ecologia, capital e cultura: racionalidade ambiental, democracia participativa e desenvolvimento sustentável. Editora da FURB. Blumenau, (Tradução de Jorge Esteves da Silva). 2000.

LEFF, Enrique. Racionalidade Ambiental:a reapropriação social da natureza.Tradução de Luiz Carlos Cabral. Rio de Janeiro: civilização brasileira.2006. 
LEFF, Enrique. Epistemologia Ambiental.(Tradução de Sandra Venezuela). $5^{\text {a }}$ edição. Ed.Cortez. São Paulo. 2010

LEFORT, Claude. A Invenção Democrática: os limites da dominação totalitária. Trad. Louveiro, Isabel M. 2a ed. São Paulo: Brasiliense, 1987.

MACHADO, Paulo Afonso Leme. Direito Ambiental Brasileiro. - $9^{\text {a }}$. ed., $2^{\mathrm{a}}$. Tiragem - São Paulo: Malheiros, 2001.

MELlO, Oswaldo Aranha Bandeira de. Princípios Gerais de Direito Administrativo. 2. ed. Rio de Janeiro: Forense, 1979, vol. 1

MILARÉ, Edis. Direito do Ambiente, Doutrina e Jurisprudência. $4^{\mathrm{a}}$ ed. São Paulo: RT, 2005.

MISHAN, Edward Joshua. Desenvolvimento... A Que Preço? Tradução de Aydano Arruda. São Paulo. IBRASA. 1976

NEDER, Ricardo Toledo. Crise Socioambiental: Estado e Sociedade civil no Brasil 1982/1998. Editora Anna Blume. São Paulo. Fapesp.2002

NETO, Shiraishi Neto. O campo Jurídico em Pierre Bourdieu: a produção de uma verdade a partir da noção de propriedade privada nos manuais de Direito. Confluências - Revista Interdisciplinar de Sociologia e Direito, Vol. 9, $\mathrm{n}^{\circ}$ 2, 2007 - pp. 125 a 142. Disponível no endereço eletrônico:Disponível em http//:www.uff.br/ppgsd/confluencias/revista-confluencia-vol 02. pdf

PARAÍSO, Maria Letícia de Souza. Metodologias de avaliação econômica dos recursos naturais. Revista deDireito Ambiental. São Paulo, n. 6, 1997.

PRIEUR, Michel. "A/HRC/34/NGO/60 Written Statement Submitted by International Center for Compared Environmental Law." Centre International de Droit Comparé de L Environnement. Accessed May 9, 2017. https://cidce.org/.

REALE, Miguel. Teoria Tridimensional do Direito. Ed. Saraiva. São Paulo. 1994.

REALE, Miguel. Lições Preliminares de Direito, 26 ed., Editora Saraiva, São Paulo. 2008.

SANTO, Mario Marcos do Espírito. Esclarecimentos técnico-científicos sobre as matas secas norte-mineiras. 2010.

SANTOS, Boaventura de S.; MARIA M.L.M.; JOÃO P. Os tribunais nas sociedadescontemporâneas. In. Revista Brasileira de Ciências Sociais, 
n.30, 1996 .

SEN, Amartya. Desenvolvimento como liberdade. Tradução: Laura Teixeira Motta, revisão técnica Ricardo Doninelli Mendes. - São Paulo: Companhia das Letras, 2010.

SEN, Amartya. El valor de la democracia. Espanha:Editoral El Viejo Topo,2006.

SILVA. José Afonso da. Curso de Direito Constitucional Positivo. 22 edição. Editora Malheiros. São Paulo.2003.

SILVA. José Afonso da. Aplicabilidade das Normas Constitucionais.6.ed. São Paulo, Malheiros,2003.

VEIGA, José Eli da. Desenvolvimento Sustentável: o desafio do século XXI. Editora: Garamond Universitária. Rio de Janeiro.2005.

VIOLA, Eduardo José. O movimento ambientalista no Brasil (1974-1986): do ambientalismo à ecopolítica. Revista Brasileira de Ciências Sociais, v.1, n.3, p. 5 a 26.

ZHOURI, Andrea. LASCHESFKI, Klemens. Desenvolvimento e Conflitos Ambientais. -Belo Horizonte: Editora UFMG, 2010.

ZHOURI, Andrea ET AL in. Processos Socioambientais nas Matas Secas do Norte de Minas: políticas de conservação e os povos do lugar. MG Biota, p.v.1, n.2, Belo Horizonte: Instituto Estadual de Florestas. Jun/jul 2008.

ZHOURI, Andrea. Justiça ambiental, diversidade cultural e accountability: desafios para a governança ambiental. Revista brasileira de ciências sociais. vol.23 nº.68 São Paulo Oct. 2008

Artigo recebido em: 26/09/2017. Artigo aceito em: 07/05/2018.

\section{Como citar este artigo (ABNT):}

GARBACCIO, G. L. PRIEUR, M. DENNY, D. M. T. REVISING ENVIRONMENTAL LAW THROUGH THE PARADIGM OF GOVERNANCE. Veredas do Direito, Belo Horizonte, v. 15, n. 31, p. 1136, jan./abr. 2018. Disponível em: <http://www.domhelder.edu.br/revista/ index.php/veredas/article/view/1181>. Acesso em: dia mês. ano. 